\title{
Effects of temperature on in vitro sediment reworking processes by a gallery biodiffusor, the polychaete Neanthes virens
}

\author{
Daniel Ouellette ${ }^{1}$, Gaston Desrosiers ${ }^{1, *}$, Jean-Pierre Gagne ${ }^{1}$, Franck Gilbert ${ }^{2}$, \\ Jean-Christophe Poggiale ${ }^{2}$, Pierre U. Blier ${ }^{3}$, Georges Stora ${ }^{2}$ \\ ${ }^{1}$ Institut des sciences de la mer de Rimouski (ISMER), Université du Québec à Rimouski, 310 allée des Ursulines, Rimouski, \\ Québec G5L 3A1, Canada \\ ${ }^{2}$ Laboratoire d'Océanographie et de Biogéochimie, Université de la Méditerranée, COM, Campus de Luminy, case 901, \\ Marseille 13288, Cedex 9, France \\ ${ }^{3}$ Département de biologie, chimie, sciences de la santé, Université du Québec à Rimouski, 300 allée des Ursulines, \\ Rimouski, Québec G5L 3A1, Canada
}

\begin{abstract}
Temperature-induced variations in bioturbation could affect sediment mixing processes in the marine benthic environment. In this study, sediment reworking by Neanthes virens (Sars), a widely distributed polychaete in muddy sand communities of northern temperate latitudes, was studied under different temperature conditions representing winter $\left(1^{\circ} \mathrm{C}\right)$, spring and fall $\left(6^{\circ} \mathrm{C}\right)$, summer $\left(13^{\circ} \mathrm{C}\right)$, and tide pool $\left(18^{\circ} \mathrm{C}\right)$ temperatures in the lower St. Lawrence Estuary, Québec, Canada. Sediment reworking was quantified using inert fluorescent particles (luminophores) deposited at the sediment surface. Based on the 1-D luminophore distributions obtained after 5 and $30 \mathrm{~d}$, the use of the specific 'gallery-biodiffusor' model allowed us to quantify both biodiffusion $\left(D_{\mathrm{b}}\right)$ and biotransport $\left(V_{\mathrm{b}}\right)$ due to the organisms. Our results showed temperature effects on sediment transport. The lowest biotransport and biodiffusion coefficients were measured at 1 and $6^{\circ} \mathrm{C}$ and did not change with time. The highest biodiffusion occurred at $13^{\circ} \mathrm{C}$ for both sampling periods. At $18^{\circ} \mathrm{C}$, biodiffusion was intermediate while biotransport was maximal. Differences between the $13^{\circ} \mathrm{C}$ biodiffusive transport and the other temperatures increased with time. Low transport values at 1 and $6^{\circ} \mathrm{C}$ suggest that a quiescent stage exists for this species at these temperatures, with sediment mixing occurring mostly during burrow construction. On the other hand, sediment mixing resulted from both the burrow construction and maintenance phases at higher temperatures $\left(13\right.$ and $\left.18^{\circ} \mathrm{C}\right)$.
\end{abstract}

KEY WORDS: Bioturbation · Temperature $\cdot$ Neanthes virens $\cdot$ Inert tracers $\cdot$ Functional groups

\section{INTRODUCTION}

Temperature is considered one of the major environmental factors affecting the life of marine organisms. Temperature variations influence geographic and bathymetric species distribution patterns (Bhaud et al. 1995, Pörtner 2001). In regions with marked seasonality, temperature is a determinant parameter that controls benthic ecosystem dynamics (Kinne 1970). Temperature affects the reproductive cycle and the duration of the planktonic larval phase (Kinne 1970,
Bhaud et al. 1995). Temperature also determines important physiological processes such as metabolism (Kinne 1970, Yokoyama 1988, Fritzsche \& von Oertzen 1995, Blier \& Lemieux 2001, Pörtner 2001), growth (Bhaud 1988), and food conversion (Neuhoff 1979). Therefore, general activities such as feeding, digestion, and locomotion, which influence bioturbation processes, are also affected by temperature (Dobbs 1983, Riisgard \& Banta 1998). For example, annelid polychaetes of the genus Nereis, which are widely distributed in coastal areas of Europe and North Amer- 
ica (Bass \& Brafield 1972, Creaser \& Clifford 1982, Kristensen 1984, Desrosiers et al. 1994), have shown large changes in pumping activity, ventilation, and oxygen uptake (Kristensen 1983, Rissgård et al. 1992) as well as in feeding and growth rates (Bass \& Brafield 1972, Neuhoff 1979, Creaser \& Clifford 1982, Kristensen 1984, Desrosiers et al. 1994) after temperature variations. This thermal sensitivity is likely related to specific adaptations and thermal tolerance. For example, Nereis diversicolor optimum temperatures are low (5 to $16^{\circ} \mathrm{C}$ ) whereas Neanthes virens and $N$. succinea prefer higher temperatures $\left(11\right.$ to $20^{\circ} \mathrm{C}$ and 20 to $35^{\circ} \mathrm{C}$ respectively) (Kristensen 1983). Therefore, considering the strong effect of temperature on physiological and metabolic processes, we can predict an important impact on the bioturbation activities of benthic organisms with changes in temperature.

The perturbation of the sedimentary environment through the activities of benthic invertebrates is known as bioturbation (Rhoads \& Young 1970, Lee \& Swartz 1980, Aller 1982) and affects many biotic and abiotic sediment parameters. When inhabited by populations of small organisms $(<1 \mathrm{~mm})$, surficial sediments become porous and unstable (Meadows \& Meadows 1991, Rowden et al. 1998). Such sediments are more fluid and friable, meaning they are more easily suspended and displaced by water currents (Grant et al. 1982). Also, burrow ventilation enhances oxygen penetration to deeper sediments (Aller 1982). This water circulation (bioirrigation) brings oxygenated water to the burrow and evacuates waste products to the water column. The presence of oxygen in deeper sediments favours the degradation of buried organic matter (OM), which then contributes to oxygen consumption and the regeneration of anoxic conditions (Kristensen et al. 1995). Intermittent bioirrigation and rapid movements of particles and solutes between different redox environments (redox oscillation) create a complex and dynamic mosaic of oxic/anoxic interfaces in sediment (Kristensen 2000) and favour OM degradation (Aller 1994) and the chemical speciation of numerous compounds (i.e. $\mathrm{Fe}^{2+}, \mathrm{Fe}^{3+}$ ) (Hulth et al. 1999).

Since bioturbation greatly modulates the physical and chemical characteristics of benthic ecosystems, many bioturbators have been identified as 'ecosystem engineers' (Lawton 1994).

To better understand the impact of bioturbation on ecosystems, the study of a dominant species is mandatory. In northern temperate latitudes, muddy sand communities are dominated by a ubiquitous polychaete, Neanthes virens (Sars) (Desrosiers \& Brêthes 1984, Commito \& Ambrose 1985). N. virens is a tubicolous organism that lives in a semi-permanent, Ushaped burrow (Bass \& Brafield 1972, Desrosiers et al. 1994). Maintenance of this burrow generates intense perturbations of the sediment column. Near the surface, sediment particles and particulate OM (POM) are moved by a biodiffusion-type transport (François et al. 2002). Biodiffusion occurs mainly in surficial sediments and is similar to molecular diffusion processes that randomly mix particles (Guinasso \& Schink 1975, Boudreau 1986a, François et al. 1997). In deeper sediments, particles are moved from the surface directly to the bottom of the burrow. This bioadvective transport (=non-local transport, sensu Boudreau 1986b, or biotransport sensu Gerino et al. 1998) results in a net transport process instead of a diffusion process (Aller \& Yingst 1978, François et al. 1997). Feeding activities such as foraging and burrow maintenance by nereids are important sources of biogenic perturbations (Charrois 1990, Gerino 1990, François et al. 1997, 2002). Because of this, seasonal temperature variations in the northern hemisphere should modulate the activity of polychaetes, which in turn might partly dictate modifications of the physico-chemical status of sediments through variations in bioturbation processes.

The aim of the present study was to examine the in vitro temperature influence on the sediment reworking kinetics induced by Neanthes virens. We designed and carried out experiments at different temperatures to determine the bioturbation effects on the vertical distribution of an inert tracer. In bioturbation studies, there are 2 main types of models: biodiffusive or bioadvective (e.g. Aller \& Yingst 1978, Boudreau 1986a, François et al. 1997). Sediment reworking resulting from the activities of tubicolous species can result in biodiffusive or bioadvective particle transport, either in succession or simultaneously in space and time (François et al. 2002). Therefore, quantitative bioturbation parameters were determined using the gallery biodiffusor model recently developed by François et al. (2002) for Nereis diversicolor.

\section{MATERIALS AND METHODS}

Experimental setting. The experiment was performed at the aquaculture research lab of the Institut des sciences de la mer de Rimouski (ISMER) in Pointeau-Père, Québec, Canada. We filled 48 cores (PVC tubes $30 \mathrm{~cm}$ in length and $10 \mathrm{~cm}$ in diameter) with fresh, screened sediment $(1 \mathrm{~mm}$ mesh to remove macrofauna) that was then covered with $10 \mathrm{~cm}$ of seawater. The microcosms were randomly distributed in water tanks set at $1,6,13$, and $18^{\circ} \mathrm{C}$ to represent winter, spring/fall, summer, and summer tide pool temperatures in the lower St. Lawrence Estuary, respectively (Desrosiers et al. 1994). Overlying seawater was renewed once every $2 \mathrm{~d}$. Aeration did not induce resuspension. Twelve microcosms were used for each 
temperature, 6 inhabited (with polychaetes) and 6 without macrofauna as experimental controls. The polychaete density used is representative of the area where they were collected (i.e. 500 ind. $\mathrm{m}^{-2}$, Desrosiers et al. 1994). Following a 1 mo stabilization period, field-collected Neanthes virens $(0.93 \pm 0.41 \mathrm{~g}$ each, mean $\pm \mathrm{SD}$ ) were added to the cores and left to acclimate for 2 wk (Miron et al. 1991) prior to luminophore addition. The worms were adequately fed with Enteromorpha sp. algae during the experiment and thus did not suffer from starvation. To quantify the sediment reworking, a frozen sediment 'cake' 1 cm thick, $10 \mathrm{~cm}$ diameter) containing $1 \mathrm{~g}$ of luminophores mixed with fresh, screened sediments (Gerino 1990, Gilbert et al. 1995) was deposited on the top of each core. The luminophores were composed of natural sediment particles ranging in size from 212 to $250 \mu \mathrm{m}$ and dyed with a fluorescent paint (Mahaut \& Graf 1987). We assumed that the tracer was inert and thus could be used as a conservative marker. Experiments were performed over $30 \mathrm{~d}$ under a 12:12 light:dark regime. In order to study the effect of temperature on both the 2 phases of $N$. virens burrow construction (i.e. building and maintenance; Miron et al. 1991), sampling occurred on Days 5 and 30 .

Sediment reworking. On each sampling day, the microcosms were frozen to terminate bioturbation activities and to facilitate the sampling processes (Gerino 1990). The frozen cores were then carefully hand sliced to obtain a set of $0.5 \mathrm{~cm}$ thick $(0$ to $2 \mathrm{~cm}$ deep), $1 \mathrm{~cm}$ thick ( 2 to $10 \mathrm{~cm}$ deep), and $2 \mathrm{~cm}$ thick (10 to $18 \mathrm{~cm}$ deep) sediment layers for each core. Each sediment sample was freeze-dried for $48 \mathrm{~h}$ and homogenized. Three subsamples of $0.25 \mathrm{~g}$ were sieved on a $250 \mu \mathrm{m}$ sieve and the luminophores were counted directly under UV light (Gerino 1990, Gilbert et al. 1995). To transform the counts of luminophores to weight for each sample, we determined a conversion factor $\left(1.3 \times 10^{-5} \mathrm{~g}\right.$ luminophore $\left.{ }^{-1}\right)$ for the luminophore mixture used in this experiment.

The biodiffusion $\left(D_{\mathrm{b}}\right)$ and biotransport $\left(V_{\mathrm{b}}\right)$ coefficients were calculated from the vertical distributions of luminophores modeled by the classical biodiffusion (Gerino et al. 1994) and gallery-biodiffusor models. The latter was specifically developed on Nereis diversicolor by François et al. (2002). This mechanistic model is time- and space-dependent and uses ordinary differential equations. It utilizes 3 kinds of parameters: (1) biological parameters such as the size of the zone affected by bioturbation, the rate of biodiffusion, and the rate of biotransport; (2) physical parameters such as the output to the water-column coefficient and the rate of physical mixing due to local water currents; and (3) biogeochemical parameters such as the tracer decay rate. A series of theoretical curves are first calculated. Using the least-square fitting method, the curve with the best fit of the observed distribution is kept and the biodiffusion and biotransport coefficients are extracted. This model is appropriate for organisms that dig galleries (François et al. 2002) as it has been observed for Neanthes virens in nature and in microcosms.

Statistical analysis. Two bioturbation models were used: the biodiffusor and the gallery-biodiffusor models (François et al. 2002). To determine the best model, we used a Kolmogorov-Smirnov goodness of fit test to compare the observed and calculated distributions (Gerino et al. 1994). Differences between the quantity of buried luminophores, the modeled biodiffusion and biotransport coefficients were studied separately using a 2-way ANOVA with time and temperature treated as fixed factors (Type I model ANOVA, Zar 1984). Bartlett's test $(\alpha=0.05)$ was employed to test a priori the homogeneity of variance. Heteroscedastic data were log- or arcsinus-transformed to obtain homogeneity of variances.

\section{RESULTS}

\section{Burying profiles}

The luminophore burying profiles showed an exponential decrease in the number of luminophores from the surface to the bottom of each core (Fig. 1). In the control cores, nearly all the luminophores remained at the surface, while $4.6 \%$ of the original amount was mixed into the sediments down to $2 \mathrm{~cm}$.

On Day 5, differences were observed among the temperature profiles. There were more luminophores between 2 and $4 \mathrm{~cm}$ at 13 and $18^{\circ} \mathrm{C}(0.082$ and $0.086 \mathrm{mg}$ luminophores $\mathrm{cm}^{-3}$, respectively) compared to the amounts found at 1 and $6^{\circ} \mathrm{C}(0.034$ and $0.055 \mathrm{mg}$ luminophores $\mathrm{cm}^{-3}$, respectively). In all cases, luminophores were buried to a maximum depth of $9 \mathrm{~cm}$. On Day 30, differences among profiles for each temperature were more pronounced and revealed 2 groupings: the lower $\left(1\right.$ and $\left.6^{\circ} \mathrm{C}\right)$ and higher $\left(13\right.$ and $\left.18^{\circ} \mathrm{C}\right)$ temperatures. The 1 and $6^{\circ} \mathrm{C}$ profiles had a steeper exponential decrease of the luminophore concentrations with depth compared to the 13 and $18^{\circ} \mathrm{C}$ profiles. Therefore, there were more luminophores buried in the sediments at 13 and $18^{\circ} \mathrm{C}$ than at 1 and $6^{\circ} \mathrm{C}$. Luminophores were found deeper in the sediments $(13 \mathrm{~cm})$ on Day 30 for all temperatures. When comparing all profiles for Day 5 and Day 30, we observed a greater quantity of luminophores buried on Day 30. Furthermore, the 1 and $6^{\circ} \mathrm{C}$ profiles on Days 5 and 30 were very similar.

On Days 5 and 30, quantity of buried luminophores differed significantly among the temperatures 


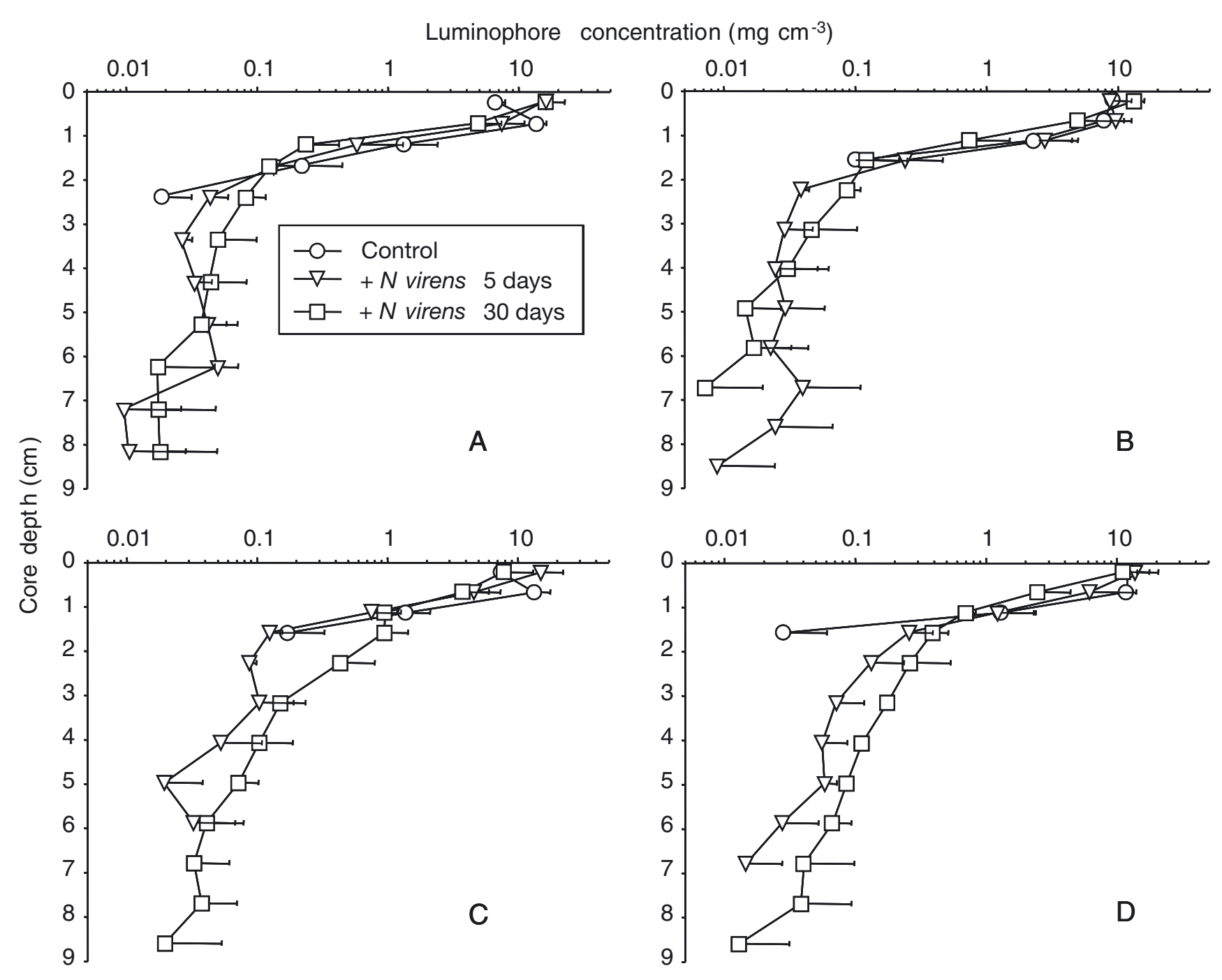

Fig. 1. Vertical distribution of luminophores in the control (Day 5) and inhabited (Days 5 and 30) sediments for each temperature: (A) $1{ }^{\circ} \mathrm{C}_{i}$ (B) $6^{\circ} \mathrm{C}_{i}$ (C) $13^{\circ} \mathrm{C}$ (D) $18^{\circ} \mathrm{C}$. Values are mean \pm SD for triplicates. Since the control profiles did not change between Days 5 and 30 , only control Day 5 profiles are presented

$\left(\right.$ ANOVA $; F_{3,20}=23.57 ; \mathrm{p}=0.001 ;$ Table 1$)$ with the highest quantities of buried luminophores found at $13^{\circ} \mathrm{C}$. The time factor (i.e. differences between the values for Days 5 and 30) also had an effect (ANOVA; $F_{1,22}$ $=15.17 ; \mathrm{p}<0.01$; Table 1 ) mainly due to the increase of the difference between the $13^{\circ} \mathrm{C}$ values and the others with time. A time $\times$ temperature interaction was noted $\left(\mathrm{ANOVA}_{i} F_{3,16}=6.217 ; \mathrm{p}<0.05 ;\right.$ Table 1$)$.

\section{Bioturbation kinetics}

Fig. 2 and Table 2 present the comparison of observed and modeled data. The results show that the observed distribution and the gallery-biodiffusor distribution over the first $7 \mathrm{~cm}$ did not differ significantly (Kolmogorov-Smirnov goodness-of-fit $\mathrm{D}_{0.05,7}=0.429$; $\mathrm{p}>0.1$ ). The difference between the observed distribution and the biodiffusor was significant $\left(D_{0.05,7}=\right.$ $0.714 ; \mathrm{p}<0.1)$. These results show that the gallerybiodiffusor model fit the Neanthes virens activities.

Table 3 and Fig. 3 present the coefficients of biodiffusion $\left(D_{\mathrm{b}} \mathrm{cm}^{2} \mathrm{~d}^{-1}\right)$ and biotransport $\left(V_{\mathrm{b}} \mathrm{cm} \mathrm{d}^{-1}\right)$ calculated for the different reworked sediments on Days 5 and 30 for the 4 experimental temperatures.

On Days 5 and 30, biodiffusion values differed significantly among the temperatures (ANOVA; $F_{3,20}=$ 9.23; $\mathrm{p}<0.01$; Table 1$)$. The highest value was at $13^{\circ} \mathrm{C}$ 
Table 1. Detailed results of the ANOVA test performed on the quantity of buried luminophores, and the $D_{\mathrm{b}}$ and $V_{\mathrm{b}}$ parameters obtained with the gallery-biodiffusor model

\begin{tabular}{|c|c|c|c|c|c|}
\hline \multicolumn{6}{|c|}{ Arcsin quantity of buried luminophores } \\
\hline Source & SS & df & MS & $F$-ratio & p-value \\
\hline Time & 0.013 & 1 & 0.013 & 15.174 & 0.0030 \\
\hline Temp. & 0.060 & 3 & 0.020 & 23.572 & 0.0001 \\
\hline Time $\times$ Temp & 0.016 & 3 & 0.005 & 6.214 & 0.0118 \\
\hline Error & 0.008 & 11 & 0.001 & & \\
\hline $\begin{array}{l}\log D_{\mathrm{b}} \\
\text { Source }\end{array}$ & SS & df & MS & F-ratio & p-value \\
\hline Time & 0.609 & 1 & 0.609 & 5.662 & 0.0365 \\
\hline Temp. & 2.979 & 3 & 0.993 & 9.228 & 0.0024 \\
\hline Time $\times$ Temp & 0.086 & 3 & 0.029 & 0.266 & 0.8482 \\
\hline Error & 1.184 & 11 & 0.108 & & \\
\hline $\begin{array}{l}\log V_{\mathbf{b}} \\
\text { Source }\end{array}$ & SS & $\mathrm{df}$ & MS & $F$-ratio & p-value \\
\hline Time & 0.444 & 1 & 0.444 & 5.081 & 0.0456 \\
\hline Temp. & 1.987 & 3 & 0.662 & 7.582 & 0.0050 \\
\hline Time $\times$ Temp & 0.102 & 3 & 0.034 & 0.391 & 0.7621 \\
\hline Error & 0.961 & 11 & 0.087 & & \\
\hline
\end{tabular}

for both periods. In addition, the difference between the $13^{\circ} \mathrm{C}$ values and the others was larger on Day 30. The time factor (i.e. differences between the values for Days 5 and 30) had a small effect $\left(\right.$ ANOVA $_{i} F_{1,22}=5.66 ; \mathrm{p}<0.1$; Table $1)$. No time $\times$ temperature interaction was noted $\left(\right.$ ANOVA $; F_{3,16}=0.27 ; \mathrm{p}=0.85$; Table 1$)$.

With the biotransport values, temperature also had a significant effect $\left(\right.$ ANOVA $_{i} F_{3,20}=7.58$; $\mathrm{p}<$ 0.01; Table 1). There were differences between the low temperatures (i.e. 1 and $6^{\circ} \mathrm{C}$ ) and $13^{\circ} \mathrm{C}$, and between the low temperatures and $18^{\circ} \mathrm{C}$. On Day 30, these differences were greater. Differences between Days 5 and 30 were slightly significant (ANOVA; $F_{1,22}=5.08 ; \mathrm{p}<0.1$; Table 1 ). No time $\times$ temperature interaction was noted $\left(\right.$ ANOVA; $F_{3,16}=0.391 ; \mathrm{p}=0.76$; Table 1 ).

\section{DISCUSSION}

The experimental setting allowed us to clearly discriminate the effect of temperature from other parameters such as food availability, light, and benthic community structure. Therefore, the observed variations of the bioturbation intensities are only associated with temperature variations. In the control sediment, no more than $4.6 \%$ of luminophores were found beneath $1 \mathrm{~cm}$ (thickness of the deposition cake) and down to $2 \mathrm{~cm}$. This may be explained by density differences between luminophores and sediments, inducing a little particle displacement toward deeper sediments. Also, meiofauna may have been responsible for this tracer migration. These small $(<1 \mathrm{~mm}$ ) organisms build microstructures that destabilize surficial sediments (Nehring et al. 1990, Giere 1993, Tita et al. 2000, Michaud et al. 2003), allowing surficial particles to penetrate deeper into the sediments (Gerino et al. 1998). However, particle displacement by meiofauna would have caused an increased penetration of the tracers with time, which was not the case in the controls between Days 5 and 30. Therefore, we conclude that meiofauna is not an important bio-

Table 2. Detailed results of the Kolmogorov-Smirnov goodness-of-fit (D) test used to compare calculated (GAL_DIF: gallery-biodiffusor model; BIODIFF: biodiffusor model) and observed distributions

\begin{tabular}{|lcccc|}
\hline $\begin{array}{c}\text { Max. negative } \\
\text { difference }\end{array}$ & $\begin{array}{c}\text { Max. positive } \\
\text { difference }\end{array}$ & $\mathrm{D}$ & $\begin{array}{c}\mathrm{p} \\
\text { level }\end{array}$ \\
\hline GAL_DIFF & -0.423 & 0.286 & 0.429 & $\mathrm{p}>0.10$ \\
BIODIFF & -0.1429 & 0.714 & 0.714 & $\mathrm{p}<0.10$ \\
\hline
\end{tabular}



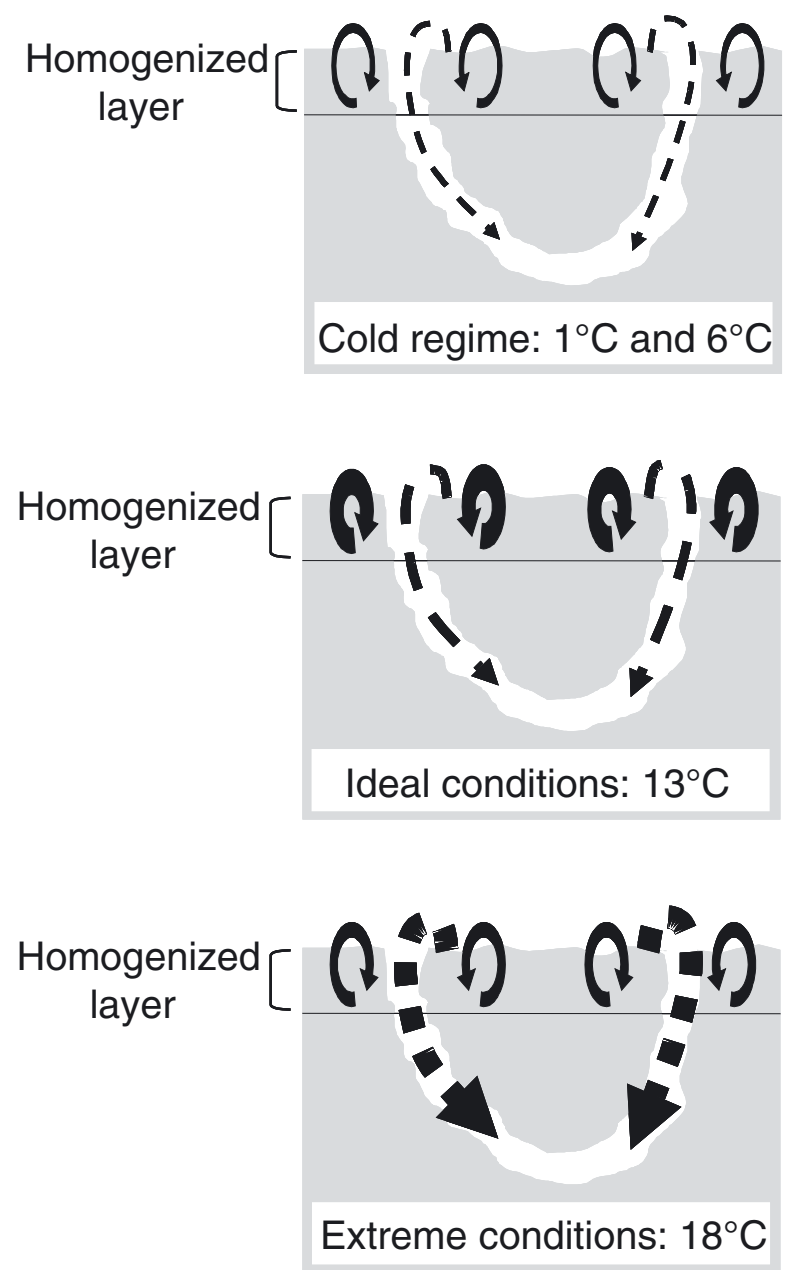

Fig. 3. Relative intensities of sediment mixing modes resulting from bioturbation activities of Neanthes virens after $30 \mathrm{~d}$. Solid arrows: biodiffusive transport $\left(D_{\mathrm{b}}\right)$; dotted arrows: bioadvective transport $\left(V_{\mathrm{b}}\right)$. Variations in the line thickness indicate the relative intensity of the transport

turbation source of our study. In the inhabited microcosms, tracer distributions were grouped into 2 temperature regimes: 1 to $6^{\circ} \mathrm{C}$ (cold) and 13 to $18^{\circ} \mathrm{C}$ (warm). The differences between the 2 regimes increased with time. The maximum depth reached by the tracers also varied with time and temperature. The luminophores were generally found deeper in microcosms sampled on Day 30. The tracers were also found deeper at warm temperatures $\left(13\right.$ and $\left.18^{\circ} \mathrm{C}\right)$.

As described by Miron et al. (1991), the construction of a new burrow by Neanthes virens is divided into 2 phases. The first phase, the building and prospecting phase, is characterized by the creation of numerous galleries due to displacements of $N$. virens in sediments. It occurs in the first 5 to $7 \mathrm{~d}$ following arrival in a new environment. When $N$. virens moves into the sediments, particles are pushed away from the poly-
Table 3. Biodiffusion $\left(D_{\mathrm{b}}\right)$ and bioadvection $\left(V_{\mathrm{b}}\right)$ coefficients calculated with the gallery-biodiffusor model in sediment cores inhabited by Nereis virens. Values are mean $\pm \mathrm{SD} ; \mathrm{n}=3$. Mean cold: average value for 1 and $6^{\circ} \mathrm{C}$ data; mean warm: average value for 13 and $18^{\circ} \mathrm{C}$ data

\begin{tabular}{|lcc|}
\hline $\begin{array}{l}\text { Temp. } \\
\left({ }^{\circ} \mathrm{C}\right)\end{array}$ & $\begin{array}{c}D_{\mathrm{b}} \\
\left(10^{-3} \mathrm{~cm}^{2} \mathrm{~d}^{-1}\right)\end{array}$ & $\begin{array}{c}V_{\mathrm{b}} \\
\left(10^{-3} \mathrm{~cm}^{2} \mathrm{~d}^{-1}\right)\end{array}$ \\
\hline $\mathbf{5 ~ d}$ & & \\
1 & $1.97 \pm 0.52$ & $1.52 \pm 0.74$ \\
6 & $3.60 \pm 2.54$ & $2.37 \pm 1.55$ \\
13 & $14.6 \pm 4.77$ & $5.65 \pm 2.28$ \\
18 & $8.64 \pm 2.07$ & $5.56 \pm 2.08$ \\
Mean cold & 2.79 & 1.95 \\
Mean warm & 11.6 & 5.60 \\
30 d & & \\
1 & $3.6 \pm 2.54$ & $2.37 \pm 1.55$ \\
6 & $9.25 \pm 6.50$ & $3.06 \pm 1.23$ \\
13 & $51.6 \pm 8.11$ & $13.9 \pm 0.03$ \\
18 & $20.8 \pm 1.47$ & $20.6 \pm 2.11$ \\
Mean cold & 6.42 & 2.71 \\
Mean warm & 36.2 & 17.3 \\
\multicolumn{2}{r}{} & \\
\hline
\end{tabular}

chaete's body. Particle movement is thus very small. Also, when moving in sediments, $N$. virens leaves a thin layer of mucus covering the walls of the newly formed galleries. One of the effects of this mucus is to hold sediment grains together to form a stable wall (Houel 1998). The consequences of these processes are low biodiffusive and bioadvective sediment transport rates. In our experiment, the polychaetes received a relatively large amount of sediments and luminophores (the cakes) that forced them to partially rebuild their burrows near the surface. Therefore, sediment reworking during this phase created relatively low biodiffusive and bioadvective transport rates on Day 5. According to Miron et al. (1991), N. virens maintains its burrow during the second phase by moving surface particles mixed with mucus to the burrow linings (maintenance phase). Particles are also moved to the burrow when $N$. virens search for food at the sediment surface. Food searching is more important during this phase than in the previous phase. By these actions, the worm increases the biodiffusive distribution in the surficial layers. Maintenance and food search also induce a rapid and direct transfer of surface particles towards the bottom of the burrow when $N$. virens moves back to its burrow (Charrois 1990). Particle movement in this manner represents bioadvective transport. The increase of both the biodiffusive and bioadvective transport measured on Day 30 is consistent with the behavioural changes by $N$. virens during the experiment.

Our results showed that both transports were affected by temperature according to the duration of the sampling periods. On Day 5, temperature seemed to have little impact on Neanthes virens activities, 
with equivalent biodiffusive and bioadvective transports for each temperature, while both processes were highly affected by temperature after $30 \mathrm{~d}$. This strongly suggests an acclimation process allowing the annelids to reduce their metabolism and activities at low temperatures while increasing them at higher temperatures. Therefore Neanthes virens, as a mesothermal invertebrate, does not compensate at low temperatures but rather decreases its activity and likely inhibits its metabolic demands to minimize its energy requirement. Conversely, active periods (high temperature) should correspond to a high availability of nutritional resources. This high thermal sensitivity of physiological processes (activity) precludes a high temperature dependence of bioturbation processes and biophysical status of sediments. Since the burrow is a vital structure (Miron et al. 1991), N. virens must rebuild it after a sediment deposition (Desrosiers et al. 1994), a process may that may be slower in a cold regime. Our results showed that biotransport and biodiffusive transport were low in the colder temperatures $\left(1\right.$ and $\left.6^{\circ} \mathrm{C}\right)$ on both Days 5 and 30 . A quiescent period induced by low temperatures, as observed in the field by Desrosiers et al. (1994), could explain the low variations observed for the bioturbation coefficients with time. At the higher temperatures (13 and $18^{\circ} \mathrm{C}$ ) after $5 \mathrm{~d}$, the biotransport and biodiffusion coefficients were close to the coldest temperature. On the other hand, after $30 \mathrm{~d}$ they were significantly higher. These temperatures correspond to summer conditions in the water column and tide pools in the lower St. Lawrence Estuary (Miron \& Desrosiers 1990). At $18^{\circ} \mathrm{C}$, the results showed a decrease in the biodiffusion coefficient and an increase in the biotransport coefficient compared to $13^{\circ} \mathrm{C}$. Bioadvective transport by polychaetes is mainly due to water currents induced by dorso-ventral oscillations of the organism (bioirrigation) that destabilize surface particles and carry them to the bottom of the burrow (François et al. 2002). Kristensen (1983) also obtained an increase in bioirrigation activities by $N$. virens at a warm $\left(20^{\circ} \mathrm{C}\right)$ temperature that was probably due to an increased demand in oxygen for metabolic activities. The low biodiffusion coefficient could be related to a reduction of food searching activities (Deschênes 2001), of particle storage in the upper part of the burrow (Olivier et al. 1996), and/or to a longer bioirrigation period by the worm (Miron et al. 1992).

Our results showed that sediment reworking processes by Neanthes virens are affected by temperature. Two temperature regimes were observed: cold and warm. Sediment reworking in the cold regime was rather low for both the biodiffusive and bioadvective transports, compared to the polychaete activities under the warm regimes.
Bioturbation has great implications in OM degradation processes. If the seasonal variability of the bioturbation intensity induces a fluctuation of these OM degradation processes, it could affect the entire organization of the intertidal ecosystem since OM regulates the life cycle of many benthic organisms (Kemp \& Boynton 1981). Consequently, the existing OM degradation estimates that are calculated on an annual basis would need seasonal corrections. Also, bioturbation models are based on steady-state or idealized conditions. They do not include temperature in the calculation of marker distribution profiles. The accuracy of bioturbation predictions would be greater with temperature-influenced models, allowing bioturbation kinetics to be evaluated on a seasonal basis instead of on an annual basis. Finally, the results also show that the thermal preferendum for Neanthes virens is narrow. In the context of global warming, the adaptability of $N$. virens populations in regions affected by large temperature variations needs further investigation.

Acknowledgements. We thank Michel Bélanger, director of the Parc du Bic, for the authorization to sample within the park, and Réal Fournier, director of the ISMER aquaculture lab, for the availability of the laboratories. We are grateful to G. Bernatchez, M. Humbert, C. Raymond, and A. Le Piouffle for help in the lab. Thanks are due to anonymous reviewers who significantly helped to improve the manuscript. We appreciate the constructive comments that Kirsten Gravel and Laure Devine made on the text. This study received financial support from the Canadian Natural Sciences and Engineering Research Council (NSERC), the Fonds pour la Formation des chercheurs et l'aide à la recherche du Gouvernement du Québec (FCAR), and the Fondation de l'UQAR. This paper is part of D. Ouellette's MSc thesis (UQAR, Oceanography). Nereis Park contribution number 010.

\section{LITERATURE CITED}

Aller RC (1982) The effects of macrobenthos on chemical properties of marine sediment and overlying water. In: McCall PL, Tevesz MJS (eds) Animal-sediment relations. Plenum Press, New York, p 53-102

Aller RC (1994) Bioturbation and remineralization of sedimentary organic matter: effects of redox oscillations. Chem Geol 114:331-345

Aller RC, Yingst JY (1978) Biogeochemistry of tube dwellings: a study of the sedentary polychaete Amphitrite ornata. J Mar Res 36:201-254

Bass NR, Brafield AE (1972) The life-cycle of the polychaete Nereis virens. J Mar Biol Assoc UK 52(3):701-725

Bhaud M (1988) Influence of temperature and food supply on development of Eupolymnia nebulosa (Montagu, 1818) (Polychaeta: Terebellidae). J Exp Mar Biol Ecol 118:103-113

Bhaud M, Cha JH, Duchêne JC, Nozais C (1995) Influence of temperature on the marine fauna: what can be expected from a climatic change. J Therm Biol 20(12):91-104

Blier PU, H Lemieux (2001) The impact of the thermal sensitivity of cytochrome oxidase on the respiration rate of Arc- 
tic charr red muscle mitochondria. J Comp Physiol B 171: 247-253

Boudreau P (1986a) Mathematics of tracer mixing in sediments: I. Spatially-dependent, diffusive mixing. Am J Sci 286:161-198

Boudreau P (1986b) Mathematics of tracer mixing in sediments: II. Non local mixing and biological conveyor-belt phenomena. Am J Sci 286:199-238

Charrois H (1990) La bioturbation estivale des Nereis (Neanthes) virens (Sars) (Polychètes) adultes: perturbations sédimentaires. MSc thesis, Université du Québec à Rimouski

Commito JA, Ambrose WG (1985) Multiple trophic levels in soft-bottom communities. Mar Ecol Prog Ser 26:289-293

Creaser EP, Clifford DA (1982) Life history studies of the sandworm, Nereis virens Sars, in the Sheepscot Estuary, Maine. Fish Bull 80(4):735-743

Deschênes J (2001) Étude des variations saisonnières du budget comportemental et de l'utilisation de la matière organique chez le polychète Nereis virens (Sars). MSc thesis, Université du Québec à Rimouski

Desrosiers G, Brêthes JC (1984) Étude bionomique de la communauté à Macoma balthica de la batture de Rimouski. Sci Tech Eau 17(1):25-30

Desrosiers G, Caron A, Olivier M, Miron G (1994) Cycle de développement d'une population intertidale de Nereis virens (Polychaeta Nereidae) de l'estuaire maritime du Saint-Laurent. Oceanol Acta 17(6):683-695

Dobbs FC (1983) Monitoring defecation activity of infaunal deposit feeders. Mar Ecol Prog Ser 12:47-50

François F, Poggiale JC, Durbec JP, Stora G (1997) A new approach for the modeling of sediment reworking induced by a macrobenthic community. Acta Biotheor 45:295-319

François F, Gerino M, Stora G, Durbec JP, Poggiale JC (2002) Functional approach to sediment reworking by galleryforming macrobenthic organisms: modeling and application with the polychaete Nereis diversicolor. Mar Ecol Prog Ser 229:127-136

Fritzsche D, von Oertzen JA (1995) Metabolic responses to changing environmental conditions in the brackish water polychaetes Marenzelleria viridis and Hediste diversicolor. Mar Biol 121:693-699

Gerino M (1990) The effects of bioturbation on particle redistribution in Mediterranean coastal sediment. Preliminary results. Hydrobiologia 207:251-258

Gerino M, Stora G, Durbec JP (1994) Quantitative estimation of biodiffusive and bioadvective sediment mixing: in situ experimental approach. Oceanol Acta 17(5):547-554

Gerino M, Aller RC, Lee C, Cochran JK, Aller JY, Green MA, Hirschberg D (1998) Comparison of different tracers and methods used to quantify bioturbation during a spring bloom: 234-Thorium, luminophores and chlorophyll a. Estuar Coast Shelf Sci 46:531-547

Giere O (1993) Meiobenthology. Springer-Verlag, Berlin

Gilbert F, Bonin P, Stora G (1995) Effect of bioturbation on denitrification in a marine sediment from the West Mediterranean littoral. Hydrobiologia 304:49-58

Grant WD, Boyer LF, Sanford LP (1982) The effects of bioturbation on the initiation of motion of intertidal sands. J Mar Res 40(3):659-677

Guinasso NL, Schink DR (1975) Quantitative estimates of biological mixing rates in abyssal sediments. J Geophys Res 80(21):3032-3043

Houel S (1998) Caractérisation de la composition chimique du mucus du polychète Nereis virens (Sars) et effets des terriers du polychète sur la distribution spatiale du carbone organique sédimentaire. MSc thesis (Oceanography), Uni- versité du Québec à Rimouski

Hulth S, Aller RC, Gilbert F (1999) Coupled anoxic nitrification/manganese reduction in marine sediments. Geochim Cosmochim Acta 63:49-66

Kemp WM, Boynton WR (1981) External and internal factors regulating metabolic rates of an estuarine benthic community. Oecologia (Berlin) 51:19-27

Kinne O (1970) Temperature: animals: invertebrates. In: Kinne O (ed) Marine ecology, Vol 1. Environmental factors, Part 1. Wiley-Interscience, London, p 407-514

Kristensen E (1983) Ventilation and oxygen uptake by 3 species of Nereis (Annelida: Polychaeta). II. Effects of temperature and salinity changes. Mar Ecol Prog Ser 12:299-306

Kristensen E (1984) Effect of natural concentrations on nutrient exchange between a polychaete burrow in estuarine sediment and the overlying water. J Exp Mar Biol Ecol 75: 171-190

Kristensen E (2000) Organic matter diagenesis at the oxic/anoxic interface in coastal marine sediments, with emphasis on the role of burrowing animals. Hydrobiologia 426:1-24

Kristensen E, Ahmed SI, Devol AH (1995) Aerobic and anaerobic decomposition of organic matter in marine sediment: Which is fastest? Limnol Oceanogr 40(8):1430-1437

Lawton JH (1994) What do species do in ecosystems? Oikos 71(3):367-374

Lee H, Swartz RC (1980) Biological processes affecting the distribution of pollutants in marine sediments. Part II. Biodeposition and bioturbation. In: Baker RA (ed) Contaminants and sediments. Vol 2, Analysis, chemistry, biology. Ann Arbor Science Publishers, Ann Arbor, MI, p 555-606

Mahaut ML, Graf G (1987) A luminophore tracer technique for bioturbation studies. Oceanol Acta 10(3):323-328

Meadows PS, Meadows A (1991) The geotechnical and geochemical implications of bioturbation in marine sedimentary ecosystems. Symp Zool Soc Lond 63:157-181

Michaud E, Desrosiers G, Long B, de Montety L and 5 others (2003) Use of axial tomography to follow temporal changes of benthic communities in an unstable sedimentary environment (Baie des Ha! Ha!, Saguenay Fjord). J Exp Mar Biol Ecol 285-286:265-282

Miron GY, Desrosiers GL (1990) Distribution and population structures of 2 intertidal estuarine polychaetes in the lower St. Lawrence Estuary, with special reference to environmental factors. Mar Biol 105:297-306

Miron G, Desrosiers G, Retière C, Lambert R (1991) Évolution spatio-temporelle du réseau de galeries chez le polychète Nereis virens (Sars) en relation avec la densité. Can J Zool 69(1):39-42

Miron G, Desrosiers G, Retière C, Masson S (1992) Variations in time budget of the polychaete Nereis virens as a function of density and acclimatation after introduction to a new burrow. Mar Biol 114:41-48

Nehring S, Jensen P, Lorenzen S (1990) Tube-dwelling nematodes: tube construction and possible ecological effects on sediment-water interfaces. Mar Ecol Prog Ser 64:123-128

Neuhoff HG (1979) Influence of temperature and salinity on food conversion and growth of different Nereis species (Polychaeta, Annelida). Mar Ecol Prog Ser 1(3):255-262

Olivier M, Desrosiers G, Caron A, Retière C (1996) Juvenile growth of the polychaete Nereis virens feeding on a range of marine vascular and macroalgal plant sources. Mar Biol 125:693-699

Pörtner HO (2001) Climate variations and the physiological basis of temperature dependent biogeography: systemic to molecular hierarchy of thermal tolerance in animals. Comp Biochem Physiol A 132:739-761 
Rhoads DC, Young DK (1970) The influence of deposit-feeding organisms on sediment stability and community trophic structure. J Mar Res 18(2):150-178

Riisgård HU, Banta GT (1998) Irrigation and deposit feeding by the lugworm Arenicola marina, characteristics and secondary effects on the environment. A review of current knowledge. Vie Milieu 48(4):243-257

Riisgård HU, Vedel A, Boye H, Larsen PS (1992) Filter-net structure and pumping activity in the polychaete Nereis diversicolor: effects of temperature and pump-modelling. Mar Ecol Prog Ser 83:79-89

Rowden AA, Jago CF, Jones SE (1998) Influence of benthic

Editorial responsibility: Otto Kinne (Editor),

Oldendorf/Luhe, Germany macrofauna on the geotechnical and geophysical properties of surficial sediment, North Sea. Cont Shelf Res 18: 1347-1363

Tita G, Desrosiers G, Vincx M, Nozais C (2000) Predation and sediment disturbance effects of the intertidal polychaete Nereis virens (Sars) on associated meiofaunal assemblages. J Exp Mar Biol Ecol 243:261-282

Yokoyama H (1988) Effects of temperature on the feeding activity and growth rate of the spionid polychaete Paraprionospio sp. (form A). J Exp Mar Biol Ecol 123:41-60

Zar JH (1984) Biostatistical analysis, 2nd edn. Prentice-Hall, Englewood Cliffs, NJ

Submitted: November 5, 2001; Accepted: November 18, 2003 Proofs received from author(s): January 19, 2004 